1

2

3

\title{
An Intertropical Convergence Zone shift controlled the terrestrial material supply on the Ninetyeast Ridge
}

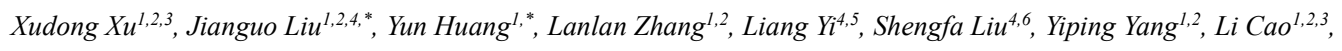

Long $\operatorname{Tan}^{1,2,3}$

${ }^{1}$ Key Laboratory of Ocean and Marginal Sea Geology, South China Sea Institute of Oceanology, Innovation Academy of South China Sea Ecology and Environmental Engineering, Chinese Academy of Sciences, Guangzhou 510301, China

${ }^{2}$ Southern Marine Science and Engineering Guangdong Laboratory (Guangzhou), Guangzhou 511458, China

${ }^{3}$ University of Chinese Academy of Science, Beijing 100049, China

${ }^{4}$ Laboratory for Marine Geology, Qingdao National Laboratory for Marine Science and Technology, Qingdao 266061,

China

${ }^{5}$ State Key Laboratory of Marine Geology, Tongji University, Shanghai 200092, China

${ }^{6}$ Key Laboratory of Marine Geology and Metallogeny, First Institute of Oceanography, Ministry of Natural Resources, Qingdao 266061, China

Corresponding authors: Jianguo Liu (jgliu@scsio.ac.cn) and Yun Huang (huangyun@scsio.ac.cn)

\section{Abstract}

Among various climate drivers, direct evidence for the Intertropical Convergence Zone (ITCZ) control of sediment supply

on the millennium scale is lacking, and the changes in ITCZ migration demonstrated in paleoclimate records need to be

better investigated. Here, we use clay minerals and Sr-Nd isotopes obtained from a gravity core on the Ninetyeast Ridge to track the corresponding source variations and analyze the relationship between terrestrial material supplementation and climatic changes. On the glacial-interglacial scale, chemical weathering weakened during the North Atlantic cold climate periods, and falling sea level hindered the transport of smectite into the study area due to the exposure of islands. However, the influence of the South Asian monsoon on the sediment supply was not obvious on the millennium scale. We suggest that the north-south migration of the ITCZ controlled the rainfall in Myanmar and further directly determined the supply 
of clay minerals on the millennium scale because the transport of smectite was highly connected with ITCZ location. Furthermore, the regional shift of the ITCZ induced an abnormal increase in the smectite percentage during the late Last Glacial Maximum (LGM) in our records. The smectite percentage in the studied core is similar to distinct ITCZ records in different time periods, revealing that regional changes in the ITCZ were significantly obvious, and that the ITCZ is not a simple N-S displacement and closer connections occurred between the Northern-Southern Hemispheres in the eastern Indian Ocean during the late Last Glacial Maximum (LGM).

\section{Introduction}

Deposited sediments are essential recorders of the paleoclimate and paleo-ocean since the climate is tied to the whole sedimentation process, from weathering and transport to the deposition of sediments on land. The terrestrial materials of "source-sink" systems are supplied to marine environments under the combined effects of multiple climate-related driving forces and ocean processes (Li et al., 2018; Yu et al., 2019), and understanding these effects is crucial for reconstructing coevolutionary relationship of the paleoenvironment with the paleo-oceans and paleoclimate. Various factors may control the formation and transport of terrestrial materials at low latitudes such as the northeastern Indian Ocean. Recently, the South Asian monsoon has been revealed to be the main driving force of terrestrial material supply in Bangladesh and of hydrological changes in the Bay of Bengal (BoB, Dutt et al. al., 2015; Gebregiorgis et al., 2016; Joussain et al., 2017; Li et al., 2018; Liu et al., 2021). Moreover, the Intertropical Convergence Zone (ITCZ) is a nonnegligible climate-driving force in low-latitude regions (Deplazes et al., 2013; Ayliffe et al., 2013), which has its pivotal role in the heat transportation on earth (Schneider et al., 2014) and the north-south shift of the ITCZ is thought to connect the climates in the Northern and Southern Hemispheres (Huang et al., 2019; Zhuravleva et al., 2021). Because the monsoon dynamics are shaped by large-scale meridional temperature gradients and an ITCZ shift in tropical monsoon area (Mohtadi et al., 2016), there are hopeful opportunities to analyze sediment response to the ITCZ or monsoon. Evidence for direct control of terrestrial sediment supply by the ITCZ remains lacking, which is an obstacle to understanding the response of the depositional 
environment to the ITCZ shift. However, the paleoclimate breakthroughs mentioned above enable us to analyze the response of sedimentary records to the ITCZ shift in the BoB more accurately.

As the main deposition area for vast amounts of weathered Himalayan materials, the BoB accumulates numerous Himalayan terrestrial materials that are loaded by the Ganges-Brahmaputra (G-B) River (Goodbred and Kuehl, 2000) and forms the largest subaqueous fan-Bengal Fan $(3000 \mathrm{~km}$ long from north to south, $1400 \mathrm{~km}$ wide from east to west, with an area of $3.9 \times 10^{5} \mathrm{~km}^{2}$; Curray et al., 2002). The eastern and western sides of the BoB correspond to the Andaman Sea and the Indian Peninsula, respectively, and the $\mathrm{BoB}$ is a natural site that is useful for studying the interactions between weathering and climatic factors since both sides of the bay are affected by the South Asian monsoon (Ali et al., 2015). Over the past twenty years, the sediment provenance in the BoB during the late Quaternary has been discussed as a hot topic, especially the provenance of sediments in the Andaman Sea (Ali et al., 2015; Awasthi et al., 2014) and in the northern (Li et al., 2018; Ye et al., 2020), western (Kessarkar et al., 2005; Tripathy et al., 2011; Tripathy et al., 2014) and eastern (Colin et al., 1999; Colin et al., 2006; Joussain et al., 2016) parts of the BoB. However, little attention has been given to sediment provenance in the southern $\mathrm{BoB}$ or, particularly, to the correlation of these sediment sources with climatic driving factors. Recent studies have revealed that clay minerals can be used to effectively track changes in source areas in the source-sink system of the BoB due to the great differences in clay mineral components among the source areas around the BoB (Joussain et al., 2016; Li et al., 2017; Liu et al., 2019a; Ye et al., 2020). Moreover, Sr-Nd isotopes have been widely reported to track the variations of sediment provenance in the BoB (Ahmad et al., 2005; Colin et al., 1999; Colin et al., 2006).

In this study, we measured clay minerals and $\mathrm{Sr}-\mathrm{Nd}$ isotopes in a deep-sea gravity core obtained from the southeastern BoB (Figure 1) to reconstruct variations in the sources of sediments in the Ninetyeast Ridge and to further explore the climate forces that affected the supply of terrestrial materials during the past $45 \mathrm{ka}$. The Ninetyeast Ridge is far from the G-B river estuary and much shallower than the underwater Bengal Fan, which makes the terrestrial sediments on the Ninetyeast Ridge suitable for exploring the relationship between the paleoclimate and paleoenvironment in the BoB. We 
aim to disentangle the ITCZ variability signal in marine sediments from multiple driving forces and further understand the response of sedimentary records to the ITCZ migrations.

\section{Material and methods}

\subsection{Chronology}

The gravity core $17 \mathrm{I} 106\left(90.0040^{\circ} \mathrm{E}, 6.2105^{\circ} \mathrm{N}\right.$, water depth $\left.2928 \mathrm{~m}\right)$ was collected by the $R / V$ Shiyan 1 vessel belonging to the South China Sea Institute of Oceanology (SCSIO), Chinese Academy of Sciences (CAS), from the Ninetyeast Ridge, northeast of the Indian Ocean (Figure 1). This core has a total length of $162 \mathrm{~cm}$ and consists of gray to green silty clays subsampled at $1-\mathrm{cm}$ intervals. The age model of core $17 \mathrm{I} 106$ was reconstructed based on 10 accelerator mass spectrometry (AMS) ${ }^{14} \mathrm{C}$ dates and Bayesian interpolations between these dates (Figure 2 and Table 1). AMS ${ }^{14} \mathrm{C}$ dating was performed on mixed planktonic foraminifera at Beta Analytic Inc. More than $20 \mathrm{mg}$ of intact mixed planktonic foraminifera shells were selected from the $>150 \mu \mathrm{m}$ fractions of each sample (10 g dried sample). All radiocarbon ages were converted and reported as calendar years before present with the Calib8.2 software program with the Marine20 calibration dataset (Reimer et al., 2020). A continuous depth-age model was performed using Bacon software by dividing a sedimentary sequence into many thin segments and estimating a linear accumulation rate for each segment based on the calibrated ${ }^{14} \mathrm{C}$ dates and a Bayesian approach (Blaauw and Christen, 2011).

\subsection{Clay mineralogy}

Clay minerals $(<2 \mu \mathrm{m})$ were separated from the sediment samples according to Stokes' settling velocity principle after organic materials and carbonates were removed with $15 \%$ hydrogen peroxide $\left(\mathrm{H}_{2} \mathrm{O}_{2}\right)$ and $0.1 \mathrm{~N}$ chlorohydric acid $(\mathrm{HCl})$, respectively. The clay mineral slides were measured using routine X-ray diffraction (XRD) equipment (Bruker Inc, D8 ADVANCE) in the Key Laboratory of Ocean and Marginal Sea Geology, SCSIO, CAS. Clay mineral abundance was calculated by measuring the peak areas of smectite (15-17 $\AA$ ), illite (10 $\AA$ ) and kaolinite/chlorite ( $7 \AA)$. Relative proportions 
of kaolinite and chlorite were calculated from the ratio of $3.57 \AA / 3.54 \AA$ peak areas. The relative percentages of the four main clay minerals were estimated by calculating the integrated peak areas of characteristic basal reflections using Topas5P software with the empirical factors by Biscaye (1965). The reproducibility error of this method is $\pm 5-10 \%$.

\subsection{Sr-Nd isotope analyses}

22 samples from core $17 \mathrm{I} 106$ were selected for isotope analyses. Strontium ( $\mathrm{Sr}$ ) and neodymium (Nd) isotopic compositions of the sediment samples were measured using a Thermo Scientific Multi-Collector Inductively Coupled Plasma Mass Spectrometer (MC-ICPMS Nu plasma) at the Key Lab of Marine Sedimentology and Environmental Geology, Ministry of Natural Resources, China. The organic materials and carbonate were removed from the samples by $\mathrm{H} 2 \mathrm{O} 2$ and $\mathrm{HCl}$, respectively. For the convenience of direct comparison, the $\mathrm{Nd}$ isotopic ratio results are expressed as $\varepsilon \mathrm{Nd}$ $(0)=[(143 \mathrm{Nd} / 144 \mathrm{Nd}) \mathrm{meas} / 0.512638-1]^{*} 10000$, using the present CHUR value (Jacobsen et al, 1980). Replicate analyses of NBS-987 during the study gave a mean $87 \mathrm{Sr} / 86 \mathrm{Sr}$ of $0.710310 \pm 0.000003$ (2s), close to its certified value of 0.710245 . Similarly, replicate analyses of JNDi-1 gave a mean $143 \mathrm{Nd} / 144 \mathrm{Nd}$ of $0.512112 \pm 0.000004$ (2s), and its certified value is 0.511860 .

\section{Results}

The age model is built based on 10 radiocarbon dates of core $17 \mathrm{I} 106$. The top age is $3.8 \mathrm{ka}$ BP and bottom age is $44.9 \mathrm{ka}$ BP, thus this core covers a continuous sedimentary succession of the last $\sim 45000$ years. The sedimentation rates in the Holocene (average $3.1 \mathrm{~cm} / \mathrm{ka}$ ) were relatively lower than those during the last glacial period (average $4.6 \mathrm{~cm} / \mathrm{ka}$ ), with the highest rate of $8.3 \mathrm{~cm} / \mathrm{ka}$ during $12.5-13.6 \mathrm{ka} \mathrm{BP}$ (Figure 3a). In the study core, illite percentage ranges from $31 \%$ to $63 \%$ with an average of $48 \%$, while smectite, percentage ranges between $8 \%$ and $57 \%$, with an average of $30 \%$ (Figure $3 \mathrm{~b}-\mathrm{e}$ ). Moreover, kaolinite percentage ranges from $2 \%$ to $16 \%$, and chlorite percentage ranges from $5 \%$ to $20 \%$ in the core sediments. In the study core, the ${ }^{87} \mathrm{Sr} /{ }^{86} \mathrm{Sr}$ ratios range from 0.7122015 to 0.7186141 with an average of 0.7161698 , while 

from -10.28 to -13.02 .

\section{Discussion}

\subsection{Sediment provenance and transport patterns}

The lower sedimentation rates $(3-5 \mathrm{~cm} / \mathrm{ka}$ ) measured in core $17 \mathrm{I} 106$ were in accordance with the normal sedimentation rates obtained from cores SK157-14, SK157-15 and SK157-16 around the Ninetyeast Ridge (Ahmad et al., 2005; Raza et al., 2013). In this region, turbidite activities were less developed (Joussain et al., 2016; Fournier et al., 2017), in accordance with its far distance from the Active Channel. In the northern BoB, due to heavy river runoff and steep topography, the GB river system transports a large amount of the products of Himalayan physical denudation; these products mainly consist of illite and chlorite formed under dry and cold climate conditions (Chamley, 1989; Khan et al., 2019). Because of the hot and humid conditions in Myanmar and the Indian Peninsula, sediments in these regions are formed through the chemical weathering of silicate minerals and thus have high smectite percentages. Moreover, the Irrawaddy River brought weathered products characterized by high smectite percentage from Myanmar into the Andaman Sea, leading to high smectite percentages in the terrestrial sediments deposited in this marine environment (Ali et al., 2015).

The relatively high illite percentages measured in core 171106 indicate that the weathered Himalayan materials carried by the G-B River system are the primary source of sediments in the study area (Figure 4a). Compared with the large amounts of materials loaded by the G-B River system, the weathered areas and runoff volumes of the Indo-Burman Ranges are relatively small, and consequently, their sediment contributions are limited in the study area, although their sediments are also characterized by relatively high illite percentages (Joussain et al., 2016). Evidence of surface sediments in the BoB 

eastern and western regions (Li et al., 2017; Liu et al., 2019a), indicating that sediments of Indian Peninsula origin are difficult to transport into the eastern BoB through the central BoB. Because the limited weathering area of AndamanNicobar islands cannot provide a large amount of smectite according to provenance studies (Ali et al., 2015), the Myanmar materials characterized by high smectite percentages have the advantage of shorter transport distances compared to those sourced from the Indian Peninsula as the main source area of smectite around the BoB, Therefore, the most important source of smectite in the study area is the Myanmar region. In marine environments, kaolinite is preferentially deposited in estuary areas due to mineral segregation (Gibbs, 1977) and thus cannot be transported over long distances, so the kaolinite in the study area was most likely sourced from neighboring Sumatra (Figure 4a, Liu et al., 2012). The Sr-Nd isotopes measured in the studied core are close to those measured in the Irrawaddy/Indo-Burman Ranges/Sumatra source regions (Figure $4 b$ ), indicating that terrestrial materials with diameters $<63 \mu \mathrm{m}$ mainly come from the Irrawaddy River, Indo-Burman Ranges and the Sumatra source areas; these source areas are closer to the study area than the G-B River system, as was confirmed by a Sr-Nd isotope study in the southwestern part of the study area (Ahmad et al., 2005). This result is not consistent with the evidence provided by clay minerals, which indicate that the Himalayas were the main sediment source. This difference may be consistent with the view that clay minerals may be transported over long distances while coarser terrestrial sediments can only be transported to more proximate locations. of core 17I106, drilled on the Ninetyeast Ridge, was above the normal seafloor, and the terrestrial materials deposited to the west of this location are difficult to resuspend and deposit on the ridge under the force of bottom currents or turbidity. 
northern strait (NS) (Figure 5, Liu et al., 2020a; Rayaroth et al., 2016); then, a westward ocean current in the middle strait (MS) loads sediments southwest into the study area (Chatterjee et al., 2017).

\subsection{Factors affecting sediment provision}

In general, illite is the major mineral produced during the strong physical erosion of metamorphic rocks and granite rocks and during the reprocessing of sedimentary rocks (Chamley, 1989; Winkler et al., 2002), while smectite is the secondary mineral produced during the chemical weathering of parent aluminosilicate and iron-magnesium silicate under warm and humid climate conditions (Chamley, 1989; Erosion, 1995). The climatic forces from the North Atlantic are thought to extensively impact the tropical Eastern Indian Ocean (EIO) and surrounding areas in the BoB (DiNezio and Tierney, 2013; Dutt et al., 2015; Gautam et al., 2020; Mohtadi et al., 2014; Peng et al., 2019; Liu et al., 2021). During the North Atlantic cold-climate periods (Heinrich events and YD period, Figure 3h) when rainfall and temperatures decreased, physical weathering was enhanced in the Himalayas (Joussain et al., 2016) while chemical weathering weakened in Myanmar and the smectite percentage thus decreased in the source area.

Sea level fluctuation is also critical in controlling the supplementation of terrestrial materials, especially clay minerals (Li et al., 2018; Liu et al., 2019a), by changing the transport paths and/or distances as well as the further input of sediments into the study area. The changing trends of the sea level in seas adjacent to the BoB (Figure 3i, Waelbroecka et al., 2002; Grant et al., 2014; Hanebuth et al., 2000; Thompson and Goldstein, 2006) are well correlated with the smectite percentages measured in core 17I106, especially during 35-21 ka, when the smectite percentages declined continuously. Since the Andaman-Nicobar Islands connecting the Andaman Sea and the BoB have continuously expanded as the sea level has continuously declined, the strait width has been consistently reduced, thereby preventing the entrance of terrestrial materials in the Andaman Sea and the further continuous decline in smectite percentages in the study area. Here, we suggest that the variations in the measured illite percentages were mainly caused by changes in smectite deposition because the 
sedimentary records obtained from the northern BoB do not support the controlling effect of the sea level on illite percentages over the past $50 \mathrm{ka}$ (Joussain et al., 2016; Li et al., 2018; Liu et al. al., 2019a).

The South Asian summer monsoon is normally thought to be an important factor affecting weathering conditions around the BoB (Dutt et al., 2015; Gebregiorgis et al., 2016; Joussain et al., 2017; Li et al., 2018; Rashid et al., 2011; Zhang et al., 2020; Zorzi et al., 2015). Stalagmites in Mawmluh Cave record variations in river runoff in the surrounding area; these variations are determined by the impacts of SST and water vapor transport paths (Dutt et al., 2015). In fact, the Mawmluh Cave records of the South Asian monsoon strength are driven by temperature gradients which drive changes in winds and moisture transport into $\mathrm{BoB}$ (Dutt et al., 2015), not just response to the rainfall amount. The smectite percentage changes measured in core 17I106 were slightly correlated after Heinrich event 1(H1) but were irrelevant before H1 (Figure 6b). This indicated the combination of temperature and moisture failed to play crucial role in smectite importation to core $17 \mathrm{I} 106$ though weathering features in the source area may be shaped by the South Asian monsoon. Moreover, the view could be confirmed by the smectite record obtained from the studied core was not well-correlated with records previously obtained in the Andaman Sea (Figure 6c,6d, Gebregiorgis et al., 2016) or with a sporopollen record obtained in Southwest China (Figure 6e,6f, Zhang et al., 2020), especially before the LGM. The consistency of salinity, SST in core SK 168 (Figure 6c,6d) and moisture, temperature Index (Figure 6e,6f) in Southwest China reveal the hydroclimate in the South Asian monsoon region might have been influenced by SST in the Indian Ocean. All these inconsistencies between smectite percentage in core 17I106 and monsoon records indicate that smectite supplementation may be mainly controlled by rainfall rather than by chemical weathering due to thermodynamic differences between sea and land environments (Liu et al., 2020b).

During the late LGM, the smectite percentage increased abnormally in core 17I106, and this increase cannot be explained by dry and cold weathering conditions, a lower sea level or a weakened summer monsoon at that time. In contrast, this abnormal change may have been attributed to an increase in the smectite input in sediments from the Burman source 

area or to a decrease in the amounts of sediments input from the Himalayas. Under the influence of the winter monsoon during the LGM, the denudated sediments on the Irrawaddy Estuary shelf may have been transported southward through the west side of Andaman Island (Prajith et al., 2018), as was confirmed in previous work showing that the winter monsoon led to an increase in terrestrial materials from the Irrawaddy River to the Ninetyeast Ridge during the Heinrich event (Ahmad et al., 2005). However, the winter monsoon was strong in the west of the study area from 21 to 15 ka (Figure 6g), and the sea level remained relatively low during that period (Gautam et al., 2020). The smectite percentages in the studied core increased significantly from 21 to $19 \mathrm{ka}$ and dropped rapidly after $19 \mathrm{ka}$. This inconsistency contradicts the conclusion that the increased smectite percentage in the source area was caused by a strong winter monsoon. Moreover, the changes in the sediment compositions measured in the Himalayan source area were probably related to variations in regional glaciers. During the LGM period, the increased glacial cover may have reduced surface runoff and furthered the transport of physical weathering products, while the increased amount of ice meltwater may have transported more illites following glacial melt. However, the reduced glacial area in the Himalayas during 18-15ka did not occur simultaneously with the increased illite percentage (Yan et al., 2020; Weldeab et al., 2019, Figure 6h). Therefore, the abnormal changes measured in the smectite percentage during the late LGM period were caused by other climate-driven mechanisms, and the millennium-scale smectite percentage fluctuations that occurred before the LGM require a more reasonable explanation.

\subsection{The ITCZ shift in the EIO}

Changes in rainfall and the corresponding runoff are generally utilized to explain short-term variations in clay minerals. In the EIO, rainfall is controlled by monsoon activities (An et al., 2011; Beck et al., 2018; Gebregiorgis et al., 2016) and/or ITCZ migrations (Deplazes et al., 2013; Stoll et al., 2007; Tan et al., 2019). As a climate-driving force in low-latitude regions, ITCZ migrations may be the main factor responsible for regional hydrological changes. During the glacialinterglacial period, the ITCZ migrated north-south and balanced thermal differences by transferring atmospheric heat; this process represents an indispensable climate-regulating power on earth (Broccoli et al., 2006; McGee et al., 2018; Schneider 

atmospheric circulation and ocean processes (Deplazes et al., 2013). The smectite particles measured in core 171106 mainly came from the Myanmar source area; in this area, rainfall is greatly affected by the seasonal shift of the ITCZ. Before the

LGM, the smectite percentages in the study core were well-matched with the ITCZ record in the Arabian Sea (Deplazes et according to record of Arabian Sea. And during cold-climate events when the ITCZ moved significantly southward, rainfall

determining the smectite percentage from the source area of Myanmar. meltwater influenced these changes. Further comparisons with IPWP records reveal that the ITCZ changes agree well with smectite percentages in core 17I106. The smectite percentage in the studied core is similar to distinct ITCZ records in 

such as the exposure of the Sunda Shelf (DiNezio and Tierney, 2013) and the effect of the thermocline in the EIO (Mohtadi et al., 2017). Thus, the regional variations in the ITCZ should be fully considered when studying climate change, especially in low-latitude regions that are sensitive to environmental changes, such as the EIO (Niedermeyer et al., 2014).

\section{Conclusion}

We reconstructed the variations in sediment sources on the Ninetyeast Ridge over the past $45 \mathrm{ka}$. The main source areas comprise the Himalayan and Irrawaddy River; sediments were stably supplied from these regions throughout the studied core. When North Atlantic cold events occurred, chemical weathering weakened and physical weathering increased; correspondingly, the smectite percentage decreased and the illite percentage increased. From $35-21 \mathrm{ka}$, the falling sea level led to an increase in the exposed area of the Andaman-Nicobar Islands and further hindered the entrance of smectite from the Andaman Sea into the study area. At the same time, the influence of the South Asian monsoon on the sediment supply was not obvious. The time-phase mismatches observed among records excluded the influence of Burman shelf sediment erosion forced by the winter monsoon or of variations in G-B river sediments induced by ice meltwater on the abnormal increases observed in the smectite percentages during the late LGM. The smectite record of core 17I106 is consistent with the ITCZ changes recorded on the millennium scale, indicating that the ITCZ controls the rainfall in the Burman source area and, further, the clay mineral variations in the study area. The inferred ITCZ shift recorded in the studied core coincided with the global ITCZ change that occurred before the LGM, but during the late LGM, the core record was consistent with the change in the regional ITCZ recorded in the EIO, indicating that the regional ITCZ was significantly connected with the Northern-Southern Hemispheres.

\section{Author contributions.}

J.L. and Y.H. conceived and designed the experiment. X.X. wrote the manuscript with contributions from all authors. L.Z. 
https://doi.org/10.5194/cp-2021-144

Preprint. Discussion started: 18 November 2021

(C) Author(s) 2021. CC BY 4.0 License. and discuss the related relevant topics of in this manuscript.

The authors declare that they have no conflict of interest.

Acknowledgements.

We thank Hui Zhang for Sr-Nd isotope measurements. Core sediment samples were collected on board of R/V "Shiyan 1"

\section{Financial support.}

(XDB42000000).

Data Availability Statement.

All

dataset

is

available

on

Science

Data

Bank

(https://www.scidb.cn/detail?dataSetId=55c7dcf1 f8344c658099dfe030264b2f).

\section{References}

Ahmad, S. M., Anil Babu, G., Padmakumari, V. M., Dayal, A. M., Sukhija, B. S., and Nagabhushanam, P.: Sr, Nd isotopic evidence of terrigenous flux variations in the Bay of Bengal: Implications of monsoons during the last $~ 34,000$ years, Geophys. Res. Lett., 32, L22711, https://doi.org/10.1029/2005GL024519, 2005.

Ahmad, S. M., Padmakumari, V. M. and Babu, G. A.: Strontium and neodymium isotopic compositions in sediments from 
Ali, S., Hathorne, E. C., Frank, M., Gebregiorgis, D., Stattegger, K., Stumpf, R., Kutterolf, S., Johnson, J. E., and Giosan, in the Andaman Sea, Geochem., Geophys., Geosy., 16, 505-521, https://doi.org/10.1002/2014gc005586, 2015.

An, Z., Clemens, S., Shen, J., Qiang, X., Jin, Z., Sun, Y., Prell, W., Luo, J., Wang, S., Xu, H., Cai, Y., Zhou, W., Liu, X., Dynamics, Science, 333, 719-723, https://doi.org/10.1126/science.1203752, 2011.

Awasthi, N., Ray, J. S., Singh, A. K., Band, S. T., and Rai, V. K.: Provenance of the Late Quaternary sediments in the Andaman Sea: Implications for monsoon variability and ocean circulation, Geochem., Geophys., Geosy., 15, 38903906, https://doi.org/10.1002/2014gc005462, 2014

Ayliffe, L. K., Gagan, M. K., Zhao, J. X., Drysdale, R. N., Hellstrom, J. C., Hantoro, W. S., Griffiths, M.L., Scott-Gagan, H., Pierre, E. S., Cowley, J. A., and Suwargadi, B. W.: Rapid interhemispheric climate links via the Australasian monsoon during the last deglaciation, Nat. Commun., 4, 2908, https://doi.org/10.1038/ncomms3908, 2013.

Beck, J. W., Zhou, W., Li, C., Wu, Z., White, L., Xian, F., Kong, X. H., and An, Z.: A 550,000-year record of East Asian monsoon rainfall from Be-10 in loess, Science, 360, 877-881, https://doi.org/10.1126/science.aam5825, 2018.

Bejugam, P., and Nayak, G. N.: Source and depositional processes of the surface sediments and their implications on productivity in recent past off Mahanadi to Pennar River mouths, western Bay of Bengal, Palaeogeogr., Palaeoclimatol., Palaeoecol., 483, 58-69, https://doi.org/10.1016/j.palaeo.2016.12.006, 2017.

Biscaye, P. E.: Mineralogy and sedimentation of recent deep-sea clay in Atlantic Ocean and adjacent seas and oceans, Geol. Soc. Amer. Bull., 76, 803-832, https://doi.org/10.1130/0016-7606(1965)76[803:masord]2.0.co;2, 1965.

Blaauw, M., and Christen, J. A.: Flexible Paleoclimate Age-Depth Models Using an Autoregressive Gamma Process, Bayesian Analysis, 6, 457-474, https://doi.org/10.1214/11-ba618, 2011. 
Broccoli, A. J., Dahl, K. A., and Stouffer, R. J.: Response of the ITCZ to Northern Hemisphere cooling, Geophys. Res. Lett., 33, L01702, https://doi.org/10.1029/2005GL024546, 2006.

Chamley, H.: Clay Sedimentology, Springer, Berlin, 623 pp., 1989.

Chatterjee, A., Shankar, D., McCreary, J. P., Vinayachandran, P. N., and Mukherjee, A.: Dynamics of Andaman Sea circulation and its role in connecting the equatorial Indian Ocean to the Bay of Bengal, J. Geophys. Res. Oceans, 122, 3200-3218, https://doi.org/10.1002/2016JC012300, 2017.

Colin, C., Turpin, L., Bertaux, J., Desprairies, A., and Kissel, C.: Erosional history of the Himalayan and Burman Ranges during the last two glacial-interglacial cycles, Earth Planet. Sci. Lett., 171, 647-660, https://doi.org/10.1016/s0012$\underline{821 \times(99) 00184-3}, 1999$.

Colin, C., Turpin, L., Blamart, D., Frank, N., Kissel, C., and Duchamp, S.: Evolution of weathering patterns in the IndoBurman Ranges over the last 280 kyr: Effects of sediment provenance on ${ }^{87} \mathrm{Sr} /{ }^{86} \mathrm{Sr}$ ratios tracer, Geochem., Geophys., Geosy., 7, Q03007, https://doi.org/10.1029/2005gc000962, 2006.

Curray, J. R., Emmel, F. J., and Moore, D. G.: The Bengal Fan: morphology, geometry, stratigraphy, history and processes, Mar. Petrol. Geol., 19, 1191-1223, https://doi.org/10.1016/S0264-8172(03)00035-7, 2002.

Deplazes, G., Lückge, A., Peterson, L. C., Timmermann, A., Hamann, Y., Hughen, K. A., Röhl, U., Laj, C., Cane, M. A., Sigman, D. M., and Haug, G. H.: Links between tropical rainfall and North Atlantic climate during the last glacial period, Nat. Geosci., 6, 213-217, https://doi.org/10.1038/ngeo1712, 2013.

DiNezio, P. N., and Tierney, J. E.: The effect of sea level on glacial Indo-Pacific climate, Nat. Geosci., 6, 485-491, https://doi.org/10.1038/ngeo1823, 2013.

Dutt, S., Gupta, A. K., Clemens, S. C., Cheng, H., Singh, R. K., Kathayat, G., and Edwards, R. L.: Abrupt changes in Indian summer monsoon strength during 33,800 to 5500years B.P., Geophys. Res. Lett., 42, 5526-5532, https://doi.org/10.1002/2015g1064015, 2015. 
Erosion, H. S.: Sedimentation and sedimentary origin of clays, in: Velde, B. (Ed.), Origin and Mineralogy of Clays. Clays Environment., Springer, Berlin, pp. 162-219, 1995.

Fournier, L., Fauquembergue, K., Zaragosi, S., Zorzi, C., Malaize, B., Bassinot, F., Joussain, R., Colin, C., Moreno, E., and Leparmentier, F.: The Bengal fan: external controls on the Holocene Active Channel turbidite activity, Holocene, 27 (6), 900-913, https://doi.org/10.1177/0959683616675938, 2017.

Gautam, P. K., Narayana, A. C., Kumar, P. K., Bhavani, P. G., Yadava, M. G., and Jull, A. J. T.: Indian monsoon variability during the last $46 \mathrm{kyr}$ : isotopic records of planktic foraminifera from southwestern Bay of Bengal, J. Quat. Sci., 36, 138-151, https://doi.org/10.1002/jqs.3263, 2020.

Gebregiorgis, D., Hathorne, E. C., Sijinkumar, A. V., Nath, B. N., Nürnberg, D., and Frank, M.: South Asian summer monsoon variability during the last $\sim 54$ kyrs inferred from surface water salinity and river runoff proxies, Quat. Sci. Rev., 138, 6-15, https://doi.org/10.1016/j.quascirev.2016.02.012, 2016.

Gibbs, R. J.: Clay mineral segregation in the marine environment, J. Sediment. Res., 47, 237-243, 1977.

Goodbred, S. L., and Kuehl, S. A.: Enormous Ganges-Brahmaputra sediment discharge during strengthened early Holocene monsoon, Geology, 28, 1083-1086, https://doi.org/10.1130/0091-7613(2000)028<1083:Egbsdd>2.3.Co;2, 2000.

Grant, K. M., Rohling, E. J., Ramsey, C. B., Cheng, H., Edwards, R. L., Florindo, F., Heslop, D., Marra, F., Roberts, A. P., Tamisiea, M. E., and Williams, F.: Sea-level variability over five glacial cycles, Nat. Commun., 5, 5076, https://doi.org/10.1038/ncomms6076, 2014.

Hanebuth, T., Stattegger, K., and Grootes, P. M.: Rapid Flooding of the Sunda Shelf: A Late-Glacial Sea-Level Record, Science, 288, 1033-1035, https://doi.org/10.1126/science.288.5468.1033, 2000.

Huang, J., Wan, S., Li, A., and Li, T.: Two-phase structure of tropical hydroclimate during Heinrich Stadial 1 and its global implications, Quat. Sci. Rev., 222, 105900, https://doi.org/10.1016/j.quascirev.2019.105900, 2019.

Jacobsen, S. B. and Wasserburg, G. J.: Sm-Nd isotopic evolution of chondrites, Earth Planet. Sci. Lett., 50, 139-155, 

https://doi.org/10.1016/0012-821x(80)90125-9, 1980.

Joussain, R., Colin, C., Liu, Z., Meynadier, L., Fournier, L., Fauquembergue, K., Zaragosi, S., Schmidt, F., Rojas, V., and Bassinot, F.: Climatic control of sediment transport from the Himalayas to the proximal NE Bengal Fan during the last glacial-interglacial cycle, Quat. Sci. Rev., 148, 1-16, https://doi.org/10.1016/j.quascirev.2016.06.016, 2016.

Joussain, R., Liu, Z., Colin, C., Duchamp-Alphonse, S., Yu, Z., Moréno, E., Fournier, L., Zaragosi, S., Dapoigny, A., Meynadier, L., and Bassinot, F.: Link between Indian monsoon rainfall and physical erosion in the Himalayan system during the Holocene, Geochem., Geophys., Geosy., 18, 3452-3469, https://doi.org/10.1002/2016gc006762, 2017.

Kessarkar, P. M., Rao, V. P., Ahmad, S. M., Patil, S. K., Kumar, A. A., Babu, G. A., Chakraborty, S., and Rajan, R. S.: Changing sedimentary environment during the Late Quaternary: Sedimentological and isotopic evidence from the distal Bengal Fan, Deep Sea Res. Pt I: Oceanogr. Res. Papers, 52, 1591-1615, https://doi.org/10.1016/j.dsr.2005.01.009, 2005.

Khan, M. H. R., Liu, J., Liu, S., Seddique, A. A., Cao, L., and Rahman, A.: Clay mineral compositions in surface sediments of the Ganges-Brahmaputra-Meghna river system of Bengal Basin, Bangladesh, Mar. Geol., 412, 27-36, https://doi.org/10.1016/j.margeo.2019.03.007, 2019.

Li, J., Liu, S., Shi, X., Feng, X., Fang, X., Cao, P., Sun, X. Q., Ye, W. X., Khokiattiwong, S., and Kornkanitnan, N.: Distributions of clay minerals in surface sediments of the middle Bay of Bengal: Source and transport pattern, Continent. Shelf Res., 145, 59-67, https://doi.org/10.1016/j.csr.2017.06.017, 2017.

Li, J., Liu, S., Shi, X., Zhang, H., Fang, X., Chen, M.-T., Cao, P., Sun, X. Q., Ye, W. X., Wu, K. K., Khokiattiwong, S., and Kornkanitnan, N.: Clay minerals and Sr-Nd isotopic composition of the Bay of Bengal sediments: Implications for sediment provenance and climate control since 40 ka, Quat. Internat., 493, 50-58, https://doi.org/10.1016/j.quaint.2018.06.044, 2018.

Licht, A. France-Lanord, C., Reisberg, L., Fontaine, C., Soe, A. N., and Jaeger, J. J.: A palaeo Tibet-Myanmar connection? 

170, 929-939, https://doi.org/10.1144/jgs2012-126, 2013.

Liu, J., He, W., Cao, L., Zhu, Z., Xiang, R., Li, T., Shi, X., and Liu, S.: Staged fine-grained sediment supply from the Himalayas to the Bengal Fan in response to climate change over the past 50,000 years, Quat. Sci. Rev., 212, 164-177, https://doi.org/10.1016/j.quascirev.2019.04.008, 2019a.

Liu, J., Zhu, Z., Xiang, R., Cao, L., He, W., Liu, S., and Shi, X.: Geochemistry of core sediments along the Active Channel, northeastern Indian Ocean over the past 50,000 years: Sources and climatic implications, Palaeogeogr., Palaeoclimatol., Palaeoecol., 521, 151-160, https://doi.org/10.1016/j.palaeo.2019.02.021, 2019b.

Liu, J. P., Kuehl, S. A., Pierce, A. C., Williams, J., Blair, N. E., Harris, C., Aung, D. W., and Aye, Y. Y.: Fate of Ayeyarwady and Thanlwin Rivers Sediments in the Andaman Sea and Bay of Bengal, Mar. Geol., 423, 106137, https://doi.org/10.1016/j.margeo.2020.106137, 2020a.

Liu, S., Li, J., Zhang, H., Cao, P., Mi, B., Khokiattiwong, S., Kornkanitnan, N., and Shi, X.: Complex response of weathering intensity registered in the Andaman Sea sediments to the Indian Summer Monsoon over the last $40 \mathrm{kyr}$, Mar. Geol., 426, 106206, https://doi.org/10.1016/j.margeo.2020.106206, 2020b.

Liu, S., Ye, W., Cao, P., Zhang, H., Chen, M. -T., Li, X., Li, J., Pan, H.-J., Khokiattiwong, S., Kornkanitnan, N., and Shi, X.: Paleoclimatic responses in the tropical Indian Ocean to regional monsoon and global climate change over the last 42 kyr, Mar. Geol., 438, 106542, https://doi.org/10.1016/j.margeo.2021.106542, 2021.

Liu, Z., Wang, H., Hantoro, W. S., Sathiamurthy, E., Colin, C., Zhao, Y., Li, J.: Climatic and tectonic controls on chemical weathering in tropical Southeast Asia (Malay Peninsula, Borneo, and Sumatra), Chem. Geol., 291, 1-12, https://doi.org/10.1016/j.chemgeo.2011.11.015, 2012.

Lupker, M., France-Lanord, C., Galy, V., Lavé, J., and Kudrass, H.: Increasing chemical weathering in the Himalayan system since the Last Glacial Maximum, Earth Planet. Sci. Lett., 365, 243-252, 

https://doi.org/10.1016/j.epsl.2013.01.038, 2013.

McGee, D., Moreno-Chamarro, E., Green, B., Marshall, J., Galbraith, E., and Bradtmiller, L.: Hemispherically asymmetric trade wind changes as signatures of past ITCZ shifts, Quat. Sci. Rev., 180, 214-228, https://doi.org/10.1016/j.quascirev.2017.11.020, 2018.

Mohtadi, M., Prange, M., Oppo, D. W., De Pol-Holz, R., Merkel, U., Zhang, X., Steinke, S., and Luckge, A.: North Atlantic forcing of tropical Indian Ocean climate, Nature, 509, 76-80, https://doi.org/10.1038/nature13196, 2014.

Mohtadi, M., Prange, M., Schefuss, E., and Jennerjahn, T. C.: Late Holocene slowdown of the Indian Ocean Walker circulation, Nat. Commun., 8, 1015, https://doi.org/10.1038/s41467-017-00855-3, 2017.

Niedermeyer, E. M., Sessions, A. L., Feakins, S. J., and Mohtadi, M.: Hydroclimate of the western Indo-Pacific Warm Pool during the past 24,000 years, Proc. Nation. Acad. Sci., 111, 9402-9406, https://doi.org/10.1073/pnas.1323585111, 2014.

Peng, J., Yang, X., Toney, J. L., Ruan, J., Li, G., Zhou, Q., Gao, H., Xie, Y., Chen, Q., and Zhang, T.: Indian Summer Monsoon variations and competing influences between hemispheres since $\sim 35$ ka recorded in Tengchongqinghai Lake, southwestern China, Palaeogeogr., Palaeoclimatol., Palaeoecol., $\quad 516, \quad$ 113-125, https://doi.org/10.1016/j.palaeo.2018.11.040, 2019.

Prajith, A., Tyagi, A., and John Kurian, P.: Changing sediment sources in the Bay of Bengal: Evidence of summer monsoon intensification and ice-melt over Himalaya during the Late Quaternary, Palaeogeogr., Palaeoclimatol., Palaeoecol., 511, 309-318, https://doi.org/10.1016/j.palaeo.2018.08.016, 2018.

Rashid, H., England, E., Thompson, L., and Polyak, L.: Late Glacial to Holocene Indian Summer Monsoon Variability Based upon Sediment Records Taken from the Bay of Bengal, Terr., Atmosp. Ocean. Sci., 22, 215-228, https://doi.org/10.3319/TAO.2010.09.17.02(TibXS), 2011.

Rayaroth, M. K., Peter, B. N., and Mahmud, M. R.: High-resolution surface circulation of the Bay of Bengal derived from 
Raza, T., and Ahmad, S. M.: Surface and deep water variations in the northeast Indian Ocean during 34-6 ka BP: evidence

$$
\text { from carbon and oxygen isotopes of fossil foraminifera, Quat. Internat., 298, 37-44, }
$$
https://doi.org/10.1016/j.quaint.2012.05.005, 2013.

Reimer, P. J., Austin, W. E. N., Bard, E., Bayliss, A., Blackwell, P. G., Bronk Ramsey, C., Butzin, M., Cheng, H., Edwards, R.L., Friedrich, M., Grootes, P. M., Guilderson, T. P., Hajdas, I., Heaton, T. J., Hogg, A. G., Hughen, K. A., Kromer, B., Manning, S. W., Muscheler, R., Palmer, J. G., Pearson, C., van der Plicht, J., Reimer, R. W., Richards, D. A., Scott, E. M., Southon, J. R., Turney, C. S. M., Wacker, L., Adolphi, F., Büntgen, U., Capano, M., Fahrni, S. M., FogtmannSchulz, A., Friedrich, R., Köhler, P., Kudsk, S., Miyake, F., Olsen, J., Reinig, F., Sakamoto, M., Sookdeo, A., and Talamo, S.: The intcal20 northern hemisphere radiocarbon age calibration curve (0-55 cal kBP), Radiocarbon, 62 , 725-757, https://doi.org/10.1017/RDC.2020.41, 2020.

Rodolfo, K. S.: Sediments of Andaman Basin, northeastern Indian Ocean, Mar. Geol., 7, 371-380, https://doi.org/10.1016/0025-3227(69)90014-0, 1969.

Schneider, T., Bischoff, T., and Haug, G. H.: Migrations and dynamics of the intertropical convergence zone, Nature, 513, 45-53, https://doi.org/10.1038/nature13636, 2014.

Schott, F. A., and McCreary, J. P.: The monsoon circulation of the Indian Ocean, Progr. Oceanogr., 51, 1-123, https://doi.org/10.1016/s0079-6611(01)00083-0, 2001.

Shankar, D., Vinayachandran, P. N., and Unnikrishnan, A. S.: The monsoon currents in the north Indian Ocean,Progr. Oceanogr., 52, 63-120, https://doi.org/10.1016/s0079-6611(02)00024-1, 2002.

Stoll, H. M., Vance, D., and Arevalos, A.: Records of the Nd isotope composition of seawater from the Bay of Bengal: Implications for the impact of Northern Hemisphere cooling on ITCZ movement, Earth Planet. Sci. Lett., 255, 213228, https://doi.org/10.1016/j.epsl.2006.12.016, 2007 
Svensson, A., Andersen, K. K., Bigler, M., Clausen, H. B., Dahl-Jensen, D., Davies, S. M., Johnsen, S. J., Muscheler, R., Parrenin, F., Rasmussen, S. O., Röthlisberger, R., Seierstad, I., Steffensen, J. P., and Vinther, B. M.: A 60000 year Greenland stratigraphic ice core chronology, Clim. Past, 4, 47-57, https://doi.org/10.5194/cp-4-47-2008, 2008

Tan, L., Shen, C. C., Lowemark, L., Chawchai, S., Edwards, R. L., Cai, Y., Breitenbach, S. F. M., Cheng, H., Chou, Y. C., Duerrast, H., Partin, J. W., Cai, W., Chabangborn, A., Gao, Y., Kwiecien, O., Wu, C. C., Shi, Z., Hsu, H. H., and Wohlfarth, B.: Rainfall variations in central Indo-Pacific over the past 2,700 y, Proc. Nation. Acad. Sci., 116, 1720117206, https://doi.org/10.1073/pnas.1903167116, 2019.

Thompson, W. G., and Goldstein, S. L.: A radiometric calibration of the SPECMAP timescale, Quat. Sci. Rev., 25, 32073215, https://doi.org/10.1016/j.quascirev.2006.02.007, 2006.

Tripathy, G. R., Singh, S. K., and Bhushan, R.: Sr-Nd isotope composition of the Bay of Bengal sediment impact of climate on erosion in the Himalaya, Geochem. J., 45, 175-186, 2011.

Tripathy, G. R., Singh, S. K., and Ramaswamy, V.: Major and trace element geochemistry of Bay of Bengal sediments: Implications to provenances and their controlling factors, Palaeogeogr., Palaeoclimatol., Palaeoecol., 397, 20-30, https://doi.org/10.1016/j.palaeo.2013.04.012, 2014.

Turner, S., and Foden, J.: U, Th and Ra disequilibria, $\mathrm{Sr}, \mathrm{Nd}$ and $\mathrm{Pb}$ isotope and trace element variations in Sunda arc lavas: predominance of a subducted sediment component, Contr. Mineral. Petrol., 142, 43-57, https://doi.org/10.1007/s004100100271, 2001.

Waelbroecka, C., Labeyrieab, L., Michela, E., Duplessya, J. C., McManusc, J. F., Lambeckd, K., Balbona, E., and Labracherie, M.: Sea-level and deep water temperature changes derived from benthic foraminifera isotopic records, Quat. Sci. Rev., 21, 295-305, https://doi.org/10.1016/s0277-3791(01)00101-9, 2002.

Weldeab, S., Rühlemann, C., Bookhagen, B., Pausata, F. S. R., and Perez - Lua, F. M.: Enhanced Himalayan Glacial Melting During YD and H1 Recorded in the Northern Bay of Bengal, Geochem., Geophys., Geosy., 20, 2449-2461, 
Winkler, A., Wolf-Welling, T., Stattegger, K., and Thiede, J.: Clay mineral sedimentation in high northern latitude deepsea basins since the Middle Miocene (ODP Leg 151, NAAG), Interna. J. Earth Sci., 91 (1), 133-148, https://doi.org/10.1007/s005310100199, 2002.

Yan, Q., Owen, L. A., Zhang, Z., Jiang, N., and Zhang, R.: Deciphering the evolution and forcing mechanisms of glaciation

Climate of the Past

Discussions

over the Himalayan-Tibetan orogen during the past 20,000 years, Earth Planet. Sci. Lett., 541, 116295, https://doi.org/10.1016/j.eps1.2020.116295, 2020.

Ye, W., Liu, S., Fan, D., Zhang, H., Cao, P., Pan, H. -J., Li, J., Li, X., Fang, X., Khokiattiwong, S., Kornkanitnan, N., and Shi, X.: Evolution of sediment provenances and transport processes in the central Bay of Bengal since the Last Glacial Maximum, Quat. Internat., (in press). https://doi.org/10.1016/j.quaint.2020.12.007, 2020.

Yu, Z., Colin, C., Wan, S., Saraswat, R., Song, L., Xu, Z., Clift, P., Lu, H., Lyle, M., Kulhanek, D., Hahn, A., Tiwari, M., Mishra, R., Miska, S., and Kumar, A.: Sea level-controlled sediment transport to the eastern Arabian Sea over the past 600 kyr: clay minerals and Sr-Nd isotopic evidence from IOD site U1457, Quat. Sci. Rev., 205, 22-34, https://doi.org/10.1016/j.quascirev.2018.12.006, 2019.

Zhang, X., Zheng, Z., Huang, K., Yang, X., and Tian, L.: Sensitivity of altitudinal vegetation in southwest China to changes in the Indian summer monsoon during the past 68000 years, Quat. Sci. Rev., 239, 106359, https://doi.org/10.1016/j.quascirev.2020.106359, 2020.

Zhuravleva, A., Hüls, M., Tiedemann, R., and Bauch, H. A.: A 125-ka record of northern South American precipitation and the role of high-to-low latitude teleconnections, Quat. Sci. Rev., 270, 107159, https://doi.org/10.1016/j.quascirev.2021.107159, 2021.

Zorzi, C., Sanchez Goñi, M. F., Anupama, K., Prasad, S., Hanquiez, V., Johnson, J., and Giosan, L.: Indian monsoon variations during three contrasting climatic periods: The Holocene, Heinrich Stadial 2 and the last interglacial-glacial 


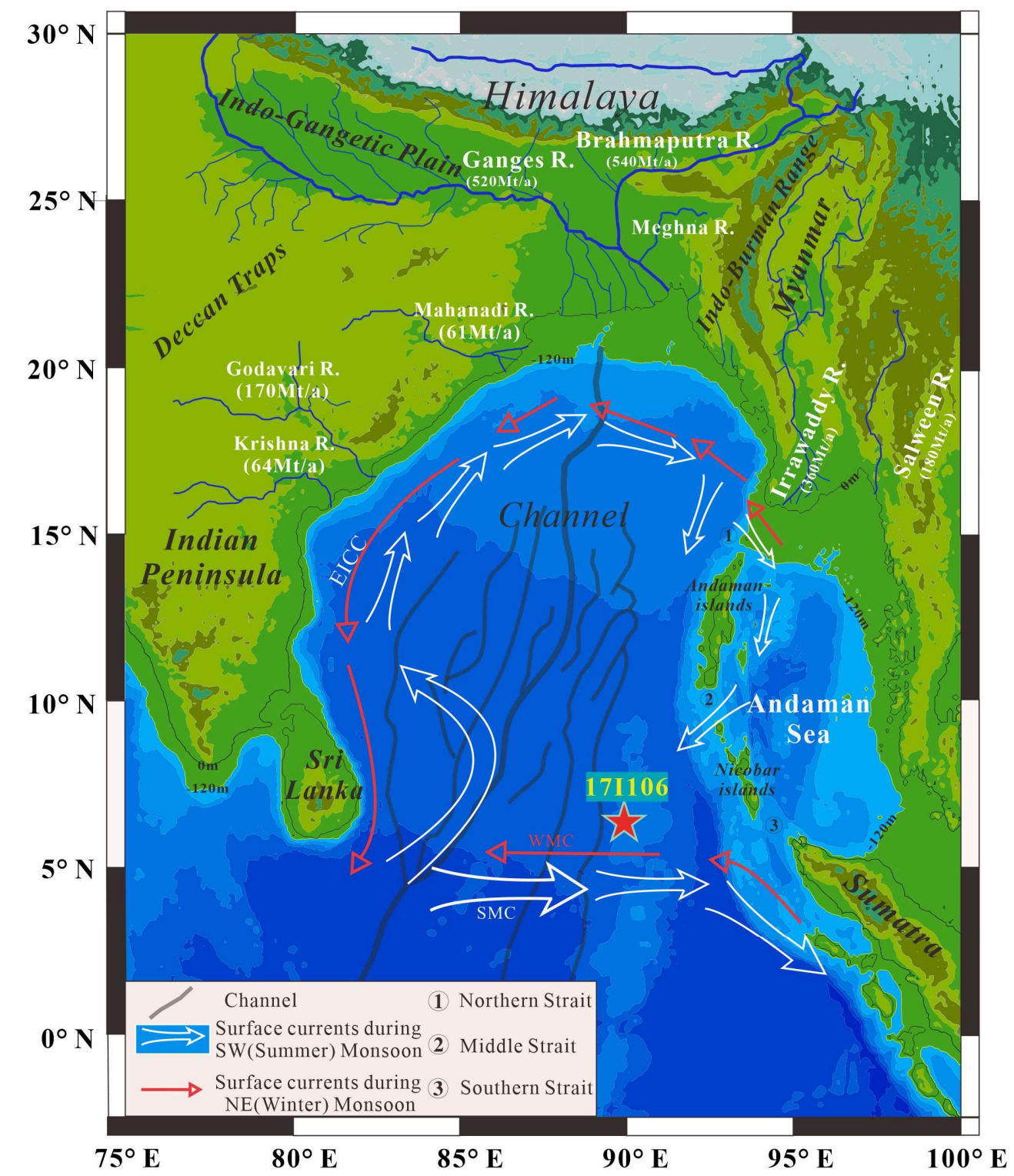

Figure 1. Geographical setting and hydrography in the BoB. The locations of core 17I106 (red asterisks) are shown. The 

in winter to form the winter monsoon current (WMC) (Shankar et al., 2002).

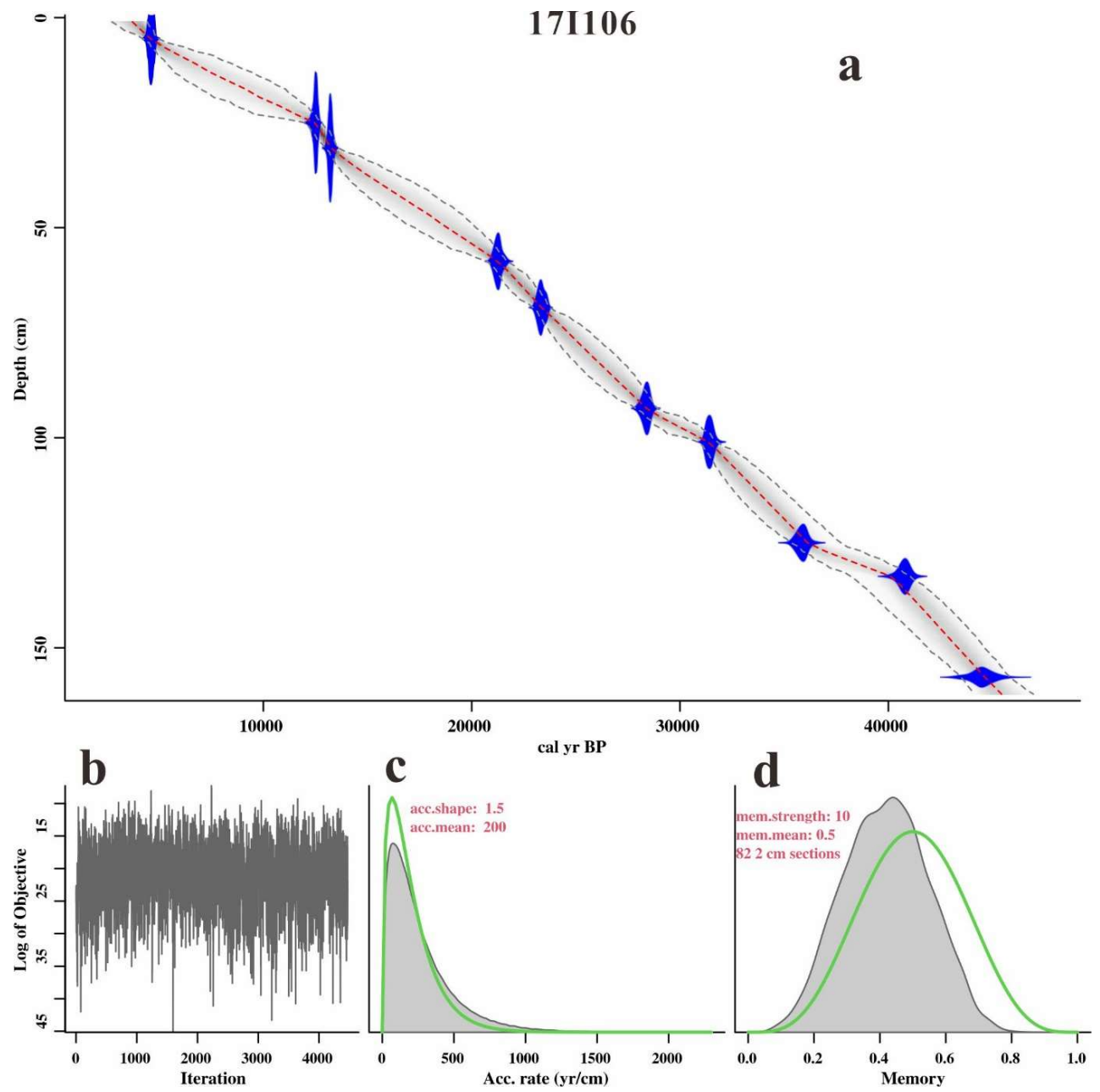

Figure 2. Age-depth model of core $17 \mathrm{I} 106$ in the northeastern Indian Ocean. a, Calibrated ${ }^{14} \mathrm{C}$ dates (blue, with $2 \sigma$ errors)

and the resulting age-depth model (the darker gray shading indicates more likely calendar ages; the gray stippled lines

show $95 \%$ confidence intervals; and the red curve shows the single 'best' model based on the weighted mean age for each 

between neighboring depths).

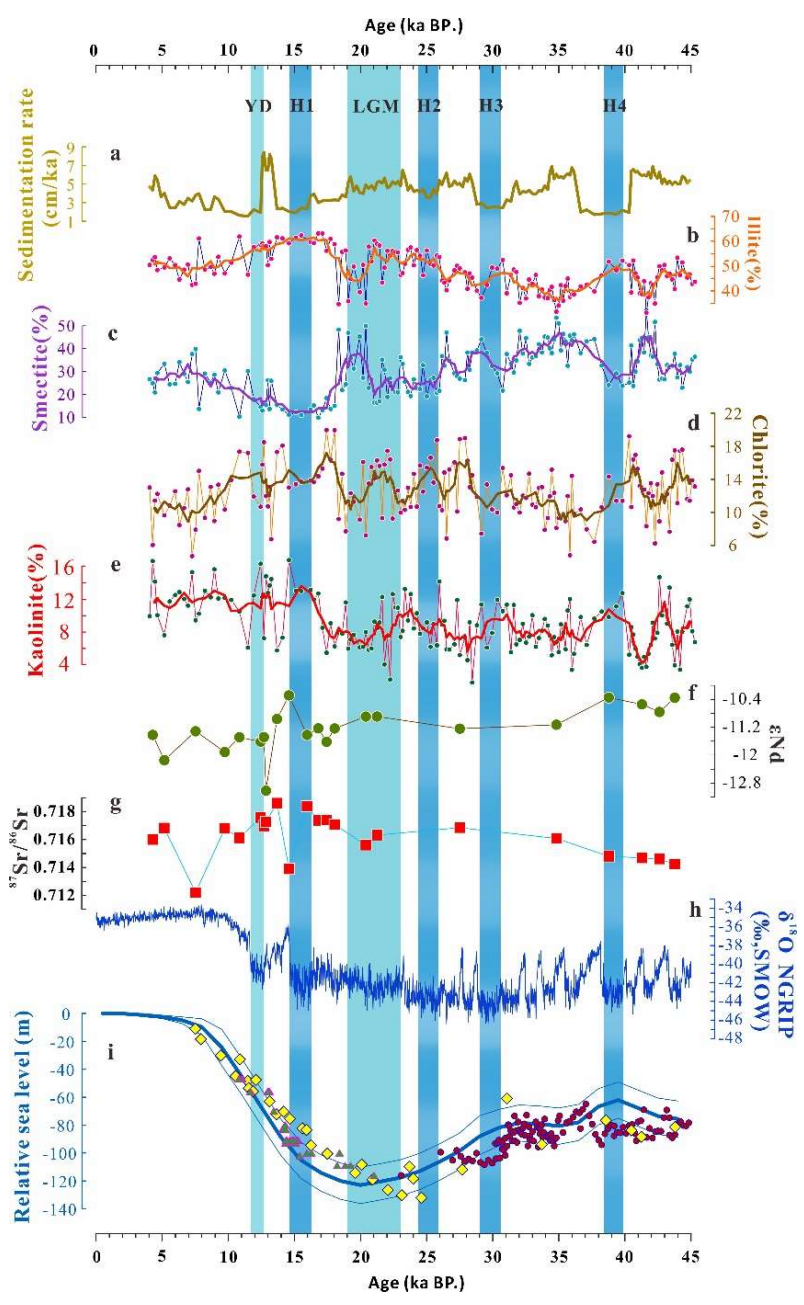

Figure 3. Comparison of clay mineral and Sr-Nd isotopes data in the northeastern Indian Ocean with paleoclimate records.

a, Sedimentation rate in core 17I106; b, c, d, e, illite, smectite, chlorite and kaolinite percentages in core $17 \mathrm{I} 106$ (thick line represents a 3-point running average); f, $\mathbf{g}{ }^{87} \mathrm{Sr} /{ }^{86} \mathrm{Sr}$ and $\varepsilon \mathrm{Nd}$ values of core $17 \mathrm{I} 106$ in the northeastern Indian Ocean; $\mathbf{h}$, $\delta^{18} \mathrm{O}$ data of Greenland ice core NGRIP; i, Global sea level as proxy for ice volume, reconstructed from benthic $\delta^{18} \mathrm{O}($ thick cyan line, thin cyan line represents the $95 \%$ confidence interval, Thompson and Goldstein, 2006), globally distributed 

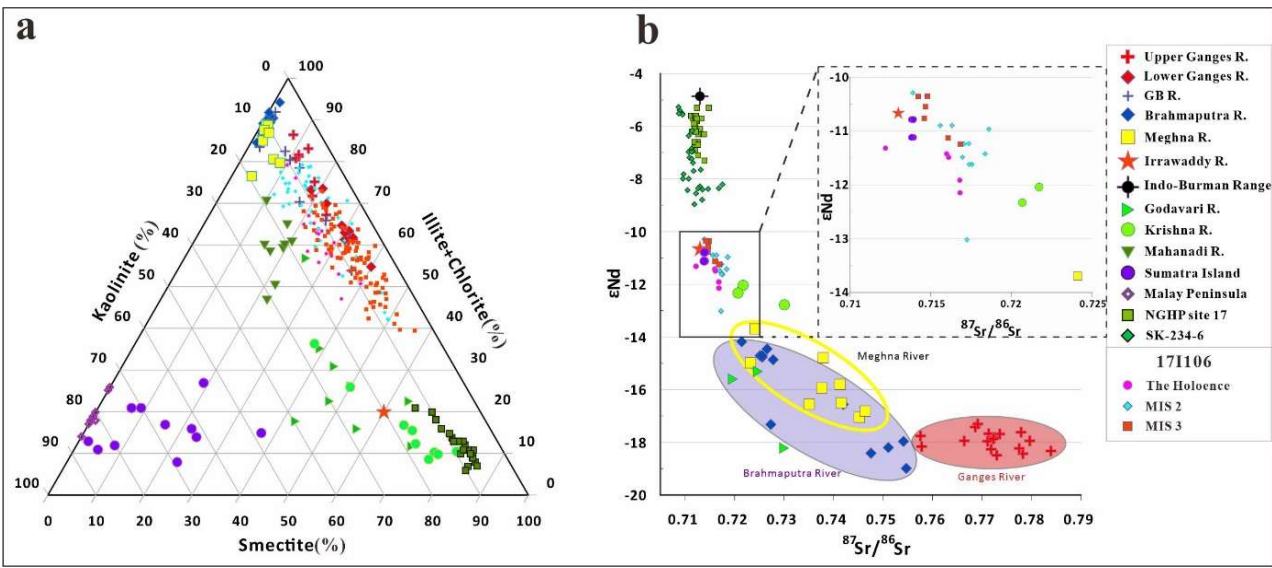

Figure 4. Sediment provenance of core $17 \mathrm{I} 106$ in the northeastern Indian Ocean. a, Sediment provenance discrimination

diagram in the northeastern Indian Ocean. For comparison, clay mineral data obtained from sediments collected in the

modern Ganges River, Brahmaputra River Lower, Ganges-Brahmaputra River Lower and Meghna River (Khan et al., 2019),

Mahanadi and Krishna Rivers of Indian Peninsula (Bejugam and Nayak, 2017), Irrawaddy River (Rodolfo, 1969), and

Sumatra and Malay Peninsula rivers (Liu et al., 2012) are also plotted. The referenced cores comprise NGHP Site 17 (Ali 
https://doi.org/10.5194/cp-2021-144

Preprint. Discussion started: 18 November 2021

(c) Author(s) 2021. CC BY 4.0 License.

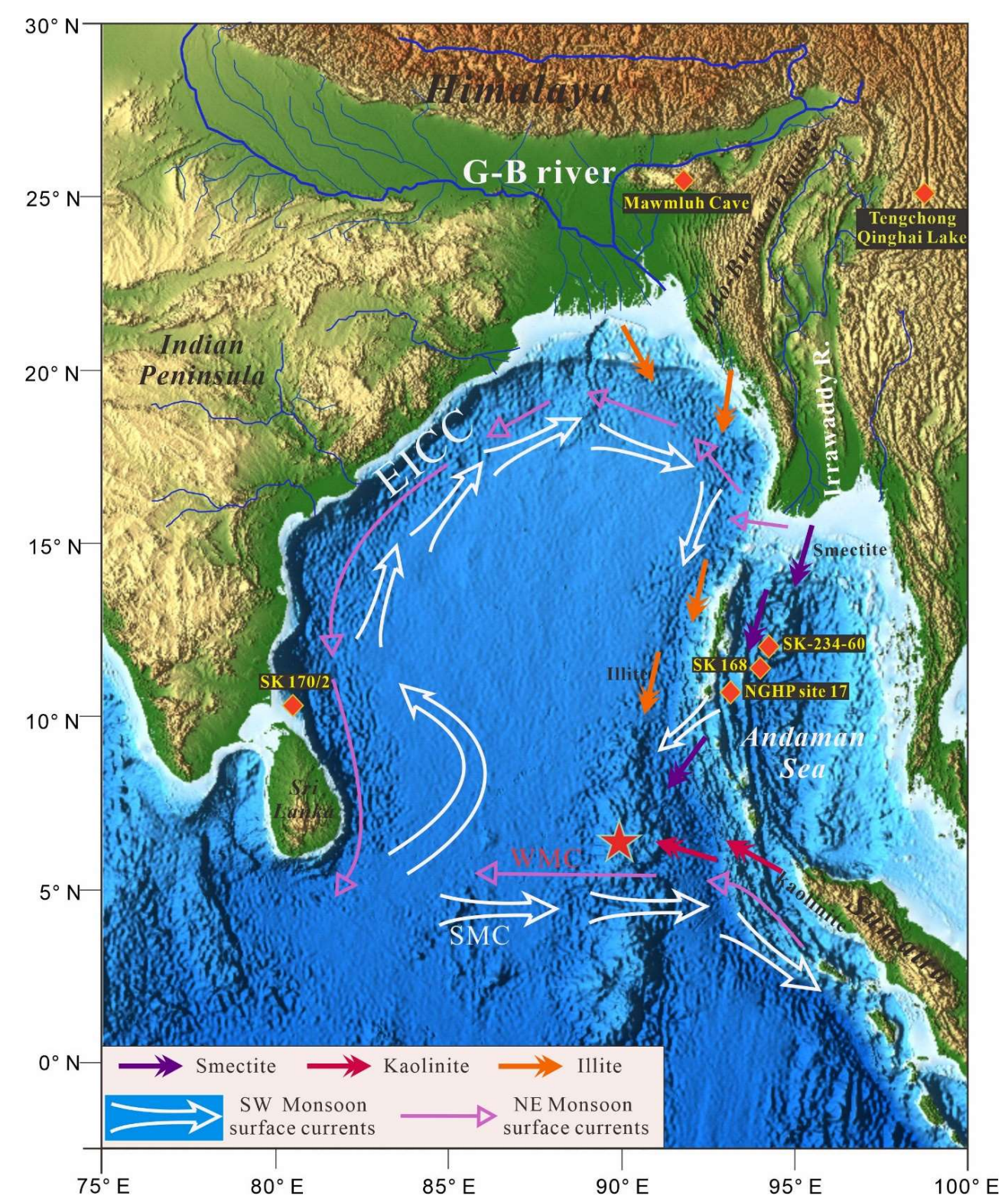

Figure 5. Map showing dispersal patterns of the BoB clay minerals for core 17I106. The locations of core $17 \mathrm{I} 106$ (red 


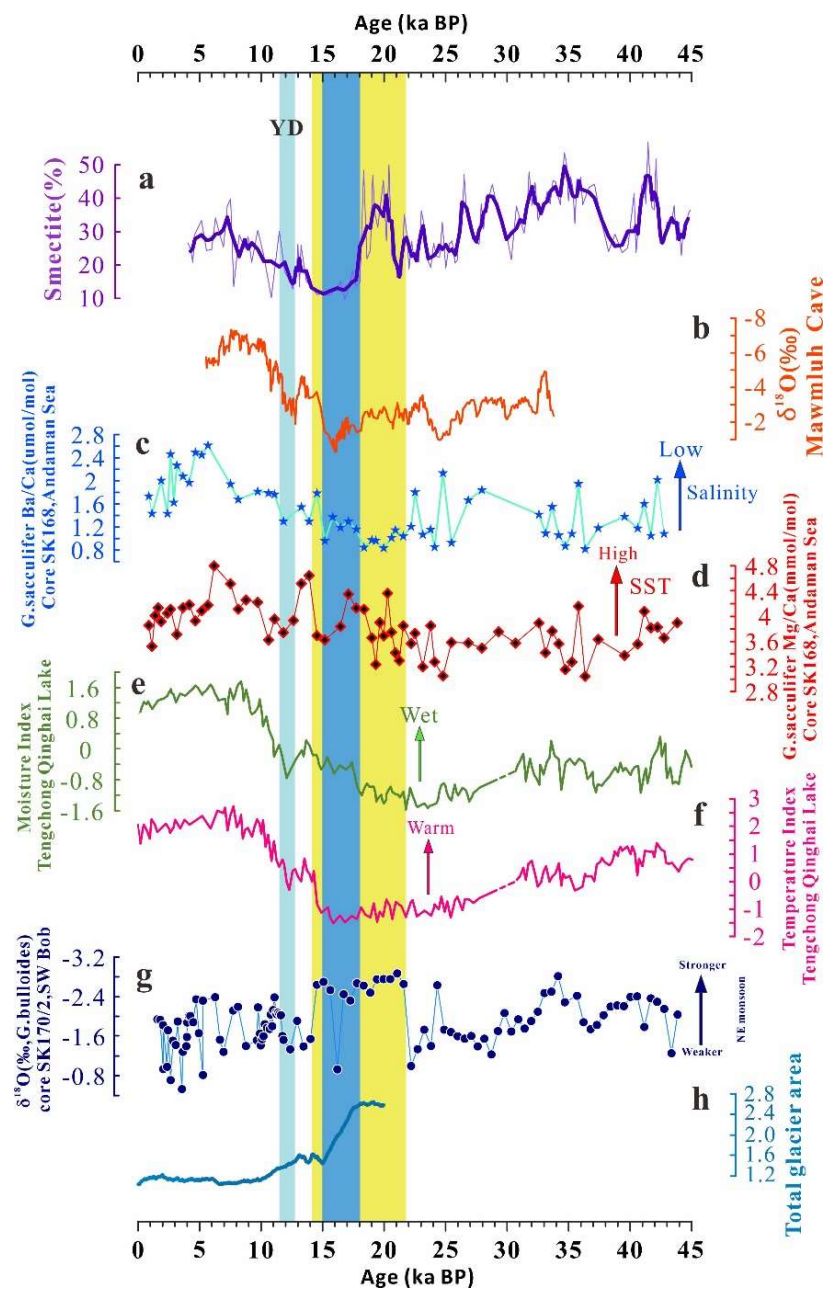

Figure 6. Comparison of smectite percentage in core $17 \mathrm{I} 106$ with paleoclimate records. a, smectite percentages in core

$17 \mathrm{I} 106$ (thick line represents a 3-point running average); b, Mawmluh Cave $\delta^{18} \mathrm{O}$ record for the interval 33,800 to 5500 
(YD).

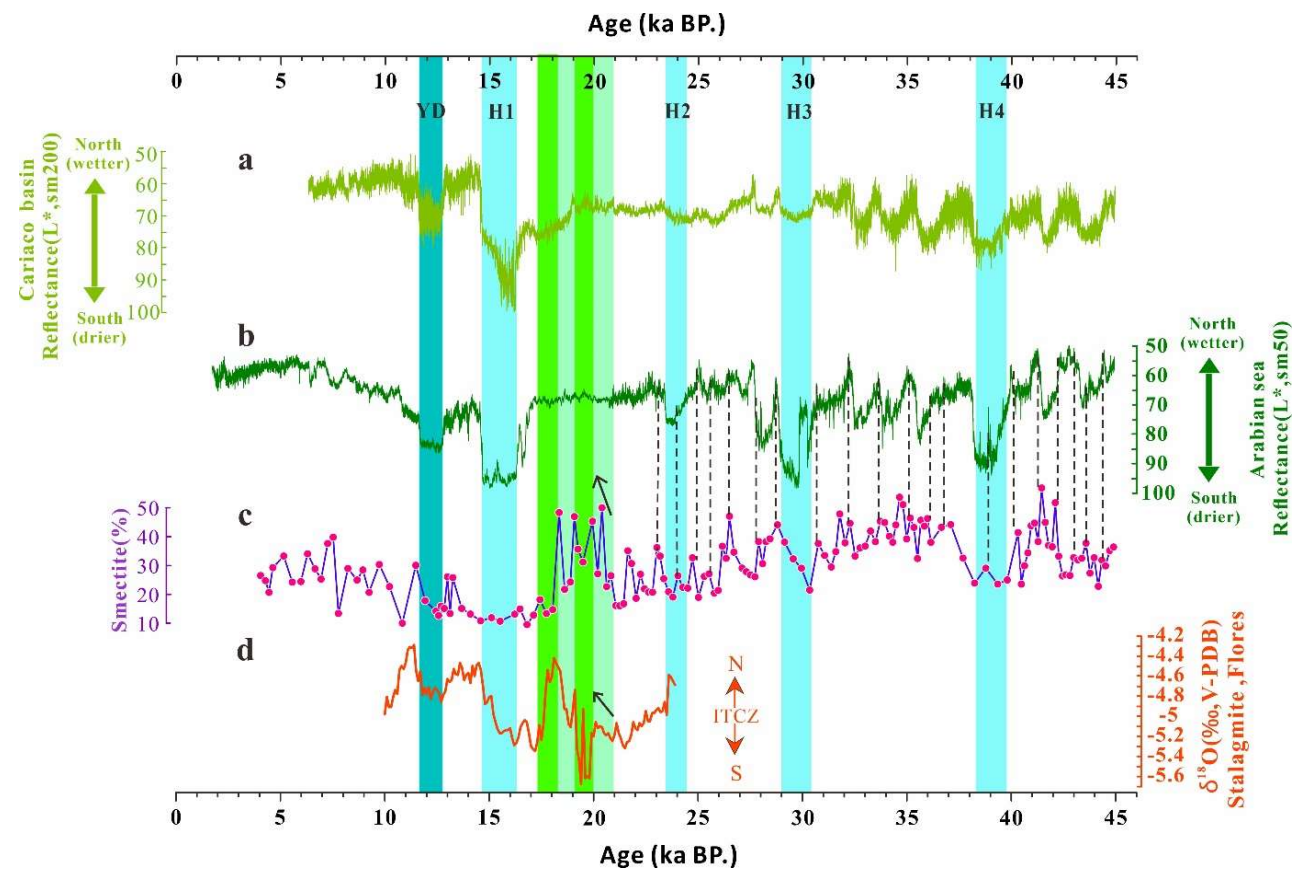

Figure 7. Comparison of smectite percentages with ITCZ north-south shift records. a, L* represents the ITCZ shift from the Cariaco Basin (Deplazes et al., 2013); b, L* represents the ITCZ shift from the Arabian Sea (Deplazes et al., 2013); c, Smectite percentages in core 17I106; d, Stalagmite $\delta^{18} \mathrm{O}$ record from Flores (Ayliffe et al., 2013). The gold dotted line denotes the connection between the northward movement of the ITCZ and the peak smectite percentage, and the series of color bars from 21-18 ka represent the ITCZ-shift periods recorded in $\mathbf{d}$. The green bars represent the consistent periods shown in $\mathbf{c}$ and $\mathbf{d}$ in the late LGM, and the black arrows in $\mathbf{c}$ and $\mathbf{d}$ indicate great differences between the smectite percentages and ITCZ record in the EIO. 
https://doi.org/10.5194/cp-2021-144

Preprint. Discussion started: 18 November 2021

(c) Author(s) 2021. CC BY 4.0 License.

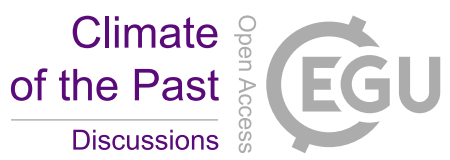

543 Table 1. Carbon-14 and calibrated calendar ages of mixed planktonic foraminifera measured in core 17 I106 in the

544 northeastern Indian Ocean.

\begin{tabular}{|c|c|c|c|c|}
\hline Number & Depth (cm) & Materials & Measured ${ }^{14} \mathrm{C}$ age $(\mathrm{yr} \mathrm{BP}, \pm 1 \sigma$ ) & Calendar median age (yr BP) \\
\hline 1 & 5 & mixed planktonic foraminifera & $4160 \pm 30$ & 4053 \\
\hline 2 & 25 & mixed planktonic foraminifera & $10690 \pm 40$ & 11880 \\
\hline 34 & 31 & mixed planktonic foraminifera & $11460 \pm 40$ & 12801 \\
\hline 4 & 58 & mixed planktonic foraminifera & $17910 \pm 50$ & 20710 \\
\hline 5 & 69 & mixed planktonic foraminifera & $20050 \pm 60$ & 23183 \\
\hline 6 & 93 & mixed planktonic foraminifera & $24590 \pm 90$ & 27883 \\
\hline 7 & 101 & mixed planktonic foraminifera & $27820 \pm 120$ & 31074 \\
\hline 8 & 125 & mixed planktonic foraminifera & $31820 \pm 200$ & 35455 \\
\hline 9 & 133 & mixed planktonic foraminifera & $36370 \pm 280$ & 40434 \\
\hline 10 & 157 & mixed planktonic foraminifera & $42190 \pm 560$ & 44167 \\
\hline
\end{tabular}

